\title{
Analysis of The Effect of Experiential Marketing And Community Reference on Purchase Decisions (Study In Surabaya Brain Coffee)
}

\author{
Novelia Asita Mranani ${ }^{1, a, \#}$, Siwidyah Desi Lastianti ${ }^{1, b}$ \\ ${ }^{1}$ Faculty of Economic, Merdeka Universty Surabaya, East Java, Indonesia

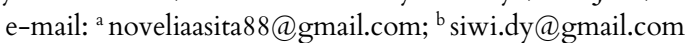 \\ ${ }^{\#}$ Corresponding Author \\ Whatsapp Number $\{+62-82333363879\}$
}

\section{ARTICLE HISTORY}

Received: 15 March 2019

Revised: 28 May 2019

Accepted: 26 June 2019

Copyright $\odot 2019$ Authors \& Published by IIES Independent. This is an open-access article distributed under the terms of the CC-BY-SA License.

\section{ABSTRACT}

The development of business today is so rapid that it creates high competition to maintain many things both in terms of survival, how to develop the company, and obtain optimal profits. Every business actor in each business category is required to have sensitivity to any changes that occur and place an orientation on customer satisfaction as the main goal. Community is increasingly important for the world of marketing. Emotional ties between members of a community have a very significant impact on a brand. The purpose of this study is to determine the influence of experiential marketing and community references partially and simultaneously on consumer purchasing decisions of Brain Coffee Surabaya. The sample of this study is Brain Coffee Surabaya consumers, with a total sample of 140 respondents. The analysis technique uses Multiple Linear Regression with SPSS programs or software. The results showed that partially experiential marketing and community reference had a positive and significant influence on purchasing decisions, as well as simultaneously (simultaneous) indicating that experiential marketing and community reference had a positive and significant influence on purchasing decisions.

Keywords: Experiential marketing; community references; purchasing decisions

How to Cite: Mranani, N., A., \& Lastianti, S., D. (2019). Analysis of The Effect of Experiential Marketing And Community Reference on Purchase Decisions (Study In Surabaya Brain Coffee). International Journal of Advances in Social and Economics, 1 (1), 36-44.

\section{Introduction}

The development of business today is so rapid that it creates high competition to maintain many things both in terms of survival, how to develop companies, and obtain optimal profits. Success in competition will be fulfilled if companies can create and retain customers (Tjiptono, 1997: 19).

Business people are Food service challenged to create a unique differentiation and positioning clearso that consumers can differentiate from their competitors. According to Mitchell (in Rahmawati, 2008) business people must prepare a strategy to be able to please and build a sense of enthusiasm for consumers to become an experience in consuming products and services, so that they will impress them. A paradigm to shift a traditional thinking in thebusiness category, food service especially cafes, which previously only provided a me- nu of food (food and drinks) just became a modern concept that offers an unforgettable experience. The creation of a comfortable atmosphere that is supported by unique interior design and the availability of various additional facilities such asmusic entertainment live, wifi and the like is in addition to being a place to meet the main needs of eating and drinking, restaurants and cafes used as a place to gather, socialize, exchange ideas , expand the network and even become one of the places for business meetings.

Purchasing decision is a decision as ownership of an action from two or more alternative choices (Sumarwan, 2003). Everyone must have considered something before making a purchase decision. Is the product to be purchased in accordance with their needs or desires. Then the product to be purchased is 
whether it is in accordance with his condition, such as the costs needed to get a desired product. But sometimes people don't consider things before making a purchase. Before buying, consumers will first make several alternative choices, whether to buy or not. If the consumer then decides one of them, then the consumer has made his decision (Sumarwan, 2003).

Schmitt in Kartajaya (2007: 228) states that in choosing a product, it is not only influenced by rational factors, but also emotional factors. This emotional factor that wants to be explored further with the concept of experiential marketing. At this stage of experiential marketing, the producer views the customer as a person who has emotional value, namely a view that emphasizes the existence of a relationship between the producer and the customer until the stage of receipt of an unforgettable experience by the customer.

Location factors also influence the decisions taken by consumers to buy a product. Locations that are easily accessible to consumers and close to crowd centers are the right location for a business, including food stalls. Before someone or a group of people decides to eat at a restaurant or cafe, they will also consider the location and atmosphere of the place to eat. Most people prefer the location of food near their home or office. In making purchasing decisions consumers will also consider situations and conditions that can lead to perceptions about the place such as the conditions of the crowd that can lead to the restaurant or cafe that many people are interested in. Design and atmosphere can also lead to perceptions, for example a simple and comfortable place will attract consumers to try because for consumers who consider the price, they will think that a simple and crowded place is enough for their pockets.

In addition, the more advertisements in the present make many consumers feel quite bored. Consumers will start looking for something clear and simple among so many information stacks. However, in a buying process a consumer is not only influenced by it, but also influenced by what iscommunicated verbally by sources that consumers believe. One source that consumers can trust is information from the community. Community is increasingly important for the world of marketing. Emotional ties between members of a community have a very significant impact on a brand. Both positive and negative impacts. Therefore brand owners should no longer see the existence of a community with one eye (Taufik, 2010).

This phenomenon also occurs in thebusiness coffee shop in Brain Coffee in Surabaya. With the shift in customer value and the number of promos and cheaper prices offered by coffee shops other, it forces marketers to think of new marketer strategies to be able to compete with developing their business. Brain Coffee has advantages such as, distinctive and distinctive flavors, varied choices of coffee flavors, comfortable and clean hangouts and many more advantages that Brain Coffee has. The purpose of Brain Coffee to open a hobby media in the middle of the village is to always educate the surrounding community to know the basic ways to distinguish the types of coffee beans, the brewing process to how to enjoy it.

According to information from the management of Brain Coffee customers not only visit one time, but repeatedly. Most consumers come together in groups. Consumers who come look comfortable with a variety of activities there, such as the presence of groups playing cards for hours, just chatting, and some even doing casual business activities, as well as teenagers who are not few.

The objectives of this study are as follows:

- To determine whether there is an influence of experiential marketing and community reference partially on purchasing decisions on Brain Coffee Surabaya.

- To determine whether there is an effect of experiential marketing simultaneousand community reference on purchasing decisions on Brain Coffee Surabaya.

This research is expected to provide input to Brain Coffee Surabaya about what marketing strategies can increase purchasing decisions. In addition, the results of this study can produce useful information as an evaluation material for effectiveness and efficiency in applying effective marketing strategies.

\section{Method}

\section{Approach}

The research approach used in this study is quantitative research through surveys. The data type used is cross section, dataie data collected once from visitors of Brain Coffee Surabaya.

Types, Data Sources, Populations, Samples and Sampling Techniques

Data used in this study are primary data, through a questionnaire. The sample is visitors to Brain Coffee Surabaya which amounted to 140 respondents. The sampling technique used in this study, namely 
nonprobability samplingsampling withtechniques using incidental sampling.

\section{Data Collection Procedure}

Collection through surveys, namely by distributingquestionnaires online (providing a google form link) to visitors of Brain Coffee Surabaya.

\section{Data Analysis Techniques}

Data in this study using multiple linear regression techniques with software SPSS.

\section{Operational Definition of Variables}

\section{Experiential Marketing (X1)}

Experiential Marketing in this research describes memory or memory, as well as experiences that are embedded in the mind as well as feelings of visitors to Brain Coffee. According to Noer Ichwan (2018) Experiential Marketing was measured using five indicators, namely:

- Sense

- Feel

- Think

- Act

- Relate

Community Reference (X2)

Community Reference in this research explain the information and experience of one group member that influences other members to persuade in purchasing at Brain Coffee. According to Schiffman (2007) community reference measured using four indicators, namely:

1. Information from group members

2. Equation tastes in groups

3. Effect of adjustments to groups

4. Recommendations from group members.

Table 1. Multicollinearity Test Results

\section{Buying Decision (Y)}

Purchasing decisions in this research describes a stage where consumers already have a choice and are ready to make a purchase or exchange between money and promises to pay with ownership rights or use of an item or service. According to Kotler \& Keller (2013: 184), purchasing decisions are measured using five indicators, namely:

1. Introduction of needs

2. Information search

3. Alternative evaluation

4. Purchasing decisions

5. Behavior after purchase

\section{Results and Discussion}

\section{Classical Assumption}

\section{Test Multicollinearity Multicollinearity}

Testtest is conducted to test whether the regression model found a correlation between independent variable. A good regression model should not have a correlation between the independent variables. Tests that have been done are whether there are symptoms of multicollinearity carried out by considering the value of the correlation matrix produced when processing data and the value of VIF (Variance Inflation Factor) and Tolerance.

If there is no correlation matrix value greater than 0.5 , it can be said that the data to be analyzed is free from multicollinearity. Then if the VIF value is below 10 and the tolerance value is close to 1 , then it is concluded that the regression model does not have multicollinearity (Singgih Santoso, 2000). The results of the multicollinearity test can be seen in Table 1 .

Collinearity Statistic

\begin{tabular}{ccc}
\hline Variabel & Toleran & VIF \\
\hline Experiential Marketing & 0,620 & 1,613 \\
\hline Referensi Komunitas & 0,620 & 1,613 \\
\hline
\end{tabular}

Source: Primary data processed, 2018. 
Based on the table 1 above it can be seen that the regression model does not experience multicollinearity disorders. This can be seen in thevalue tolerance of each variable greater than 10 percent $(0.1)$. The results of the VIF count also show that the VIF value of each variable is less than 10. Then it can be concluded that there is no multicollinearity between the independent variables in the regression model.

\section{Heteroscedasticity Test Heteroscedasticity}

Test is done to test whether in a regression model there is an inequality of residual variance from one observation to another observation, then it is called Heteroscedasticity (Singgih Santoso, 2000). One way to detect heteroscedasticity is to look at a scatter plot graph between the predicted value of the dependent variable (ZPRED) and its residual value (SRESID). If the points form a certain pattern that is regular like a large wave widens, then narrows, heteroscedasticity has occurred. If the points spread above and below number 0 on the $\mathrm{Y}$ axis without forming a certain pattern, heteroscedasticity does not occur. The results of the heteroscedasticity test from the SPSS program can be seen in the following Figure 1.

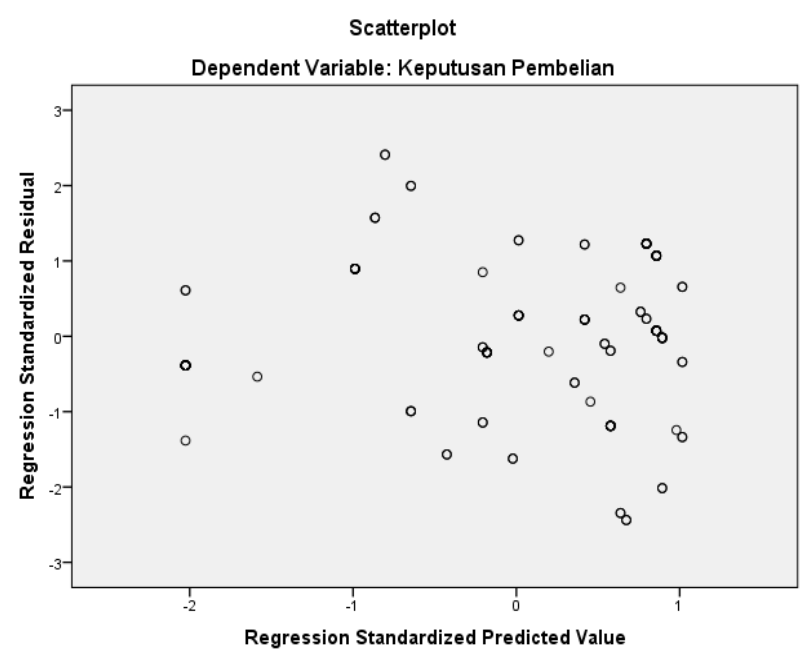

Figure 1. Heteroscedasticity Test Results Source: Primary data processed, 2018

In Figure 1 it can be seen that the points on thegraph scatterplot do not have a clear spread pattern and those points spread above and below the number 0 on the $Y$ axis. This shows that there is no heteroscedasticity disturbance in the regression model.

\section{Normality Test The}

Purpose of the normality test is to test whether in a regression model, the dependent variable and the independent variable or both have a normal distribution or not. A good regression model is normal or near normal data distribution. Normality detection is done by looking at thegraph Normal Probability Plot (Ghozali, 2005).

To test whether the data distribution is normal or not, it can be done by looking at a normal probability plot graph that compares the cumulative distribution of the actual data with the cumulative distribution of the normal distribution. If the data spreads around the line and follows the direction of the diagonal line, the regression model satisfies the normality assumption but if the data spreads far from the diagonal line and or follows the direction of the diagonal line, the regression model does not meet the assumption of normality. The results of the normality test can be seen in Figure 2.

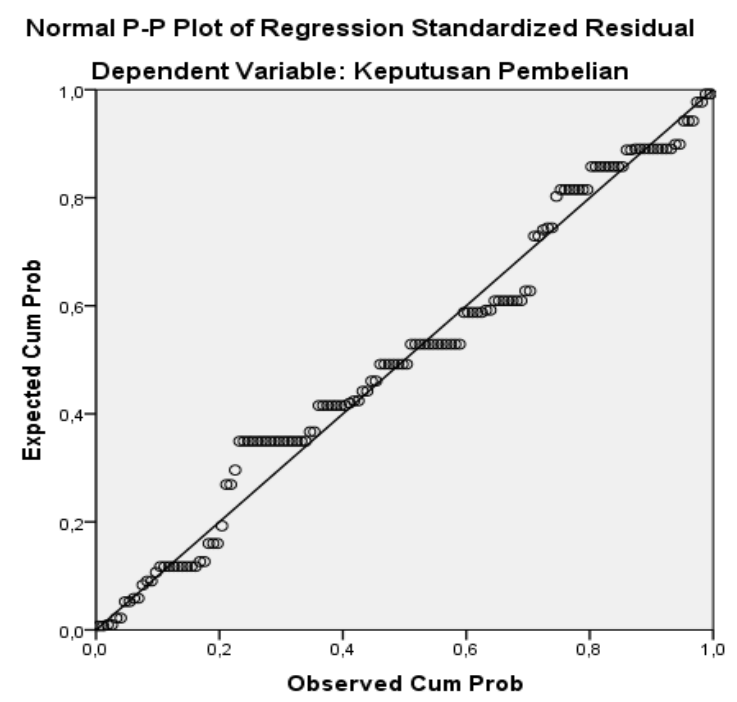

Figure 2. Normality Test Results Source: Primary data processed, 2018

In Figure 2 it can be seen that the normal probability plot graph shows a normal graph pattern. This can be seen from the point that spreads around the normal graph. This can be seen from the points that spread around the diagonal line and the spread follows the diagonal line. Therefore, it can be concluded that the regression model is feasible because it meets the assumptions of normality.

\section{Autocorrelation}

Test The autocorrelation test aims to test whether in the linear regression model there is a correlation between the error in period $t$ and the interruption error in period t-1 (before). Detection of autocorrelation is done by the Durbin-Watson Statistical Test (Ghozali, 2013: 110). 
Table 2. Autocorrelation Test Results

Model Summary ${ }^{\mathrm{b}}$

\begin{tabular}{cccccc}
\hline Model & R & R Square & Adjusted R Square & Std. Error of the Estimate & Durbin-Watson \\
\hline 1 &, $935^{\mathrm{a}}$ &, 873 &, 872 & 1,00290 & 1,949 \\
\hline
\end{tabular}

a. Predictors: (Constant), Referensi Komunitas, Analysis of Multiple Linear Regression
Experiential Marketing

b. Dependent Variable: Keputusan Pembelian

Based on Table 2 from the autocorrelation test, the calculation of Durbin-Watson value shows that it has a value of 1.949, meaning autocorrelation problems because Durbin-Watson is at $\mathrm{du}<\mathrm{d}<4-\mathrm{du}$ which is $1,695<1,949>1,752$.
This study uses multiple linear regression to prove the research hypothesis. This analysis uses inputs based on data obtained from questionnaires. The results of data processing using the SPSS program are complete in the appendix and then summarized as follows:

Table 3. Results of Multiple Linear Regression Analysis Coefficients ${ }^{\mathrm{a}}$

\begin{tabular}{|c|c|c|c|c|c|c|c|c|}
\hline & \multirow{2}{*}{ Model } & \multicolumn{2}{|c|}{ Unstandardized Coefficients } & \multirow{2}{*}{$\frac{\text { Standardized Coefficients }}{\text { Beta }}$} & \multirow{2}{*}{$\mathrm{t}$} & \multirow{2}{*}{ Sig. } & \multicolumn{2}{|c|}{ Collinearity Statistics } \\
\hline & & $\mathrm{B}$ & Std. Error & & & & Tolerance & VIF \\
\hline \multirow{3}{*}{1} & (Constant) & 1,964 &, 486 & & 4,038 &, 000 & & \\
\hline & $\begin{array}{l}\text { Experiential } \\
\text { Marketing }\end{array}$ &, 575 & ,026 & ,866 & 22,416 & ,000 & ,620 & 1,613 \\
\hline & $\begin{array}{l}\text { Referensi } \\
\text { Komunitas }\end{array}$ & 161 & 059 & ,106 & 2,740 & ,007 & ,620 & 1,613 \\
\hline
\end{tabular}

a. Dependent Variable: Keputusan Pembelian

Based on data in table 3 where the regression analysis results are obtained as follows:

$\mathrm{Y}=1,964+0,575 \mathrm{X} 1+0,161 \mathrm{X} 2$

the results of multiple linear regression analysis is still shaped figures can be explained in language that is easy to understand as to which of the following:

Constant $=1.964$ can be explained that the magnitude of the constants of 1.964 indicates that if there is no variable experiential marketing $\left(\mathrm{X}_{1}\right)$ and the reference community $\left(\mathrm{X}_{2}\right)$, then the purchase decision is 1,964 units.

$\mathrm{b} 1=0.575$ The value of 0.575 in thevariable experiential marketing $\left(\mathrm{X}_{1}\right)$ is positive so it can be said that the higher the experiential marketing given by Brain Coffee Surabaya, the higher the purchasing decision.

$\mathrm{b} 2=0.161$ The value of 0.161 in the community reference variable $\left(\mathrm{X}_{2}\right)$ is positive so it can be said that the higher the community reference given by Brain Coffee Surabaya, the higher the purchase decision.

\section{Testing Statistical Hypotheses}

\section{Test}

Basically, the $\mathrm{T}$ test shows how far the influence of one independent variable partially explains the variation of the dependent variable. The results of data processing using the SPSS program are complete in the appendices and are summarized as follows:

Table 4. Partial Test Results (T-Test)

\begin{tabular}{ccc}
\hline Model & $\mathrm{T}$ & Sig. \\
\hline$($ Constant $)$ & 4,038 &, 000 \\
\hline $\mathrm{X}_{1}$ & 22,416 &, 000 \\
\hline $\mathrm{X}_{2}$ & 2,740 &, 007 \\
\hline
\end{tabular}

Coefficient results through hypothesis testing and then compared with $\mathrm{T}$ tables, namely $\mathrm{n}=$ number of samples 140 with $\alpha=0.05$, then obtained $\mathrm{T}$ table of 1.6581 . So the results of each variable can be known which variables influence the purchasing decision as follows:

$\mathrm{H}_{1}$ : Test thehypothesis experiential marketing of the purchasing decision from the calculation results obtained by $\mathrm{T}$ count for $\mathrm{X}_{1}$ for 22.416 is greater than $\mathrm{T}$ table 1.6581 with a significance of 0.000 smaller than the significance level of 0.05 . Means that conclusions can be drawn Ho rejected, then this shows that thevariable experiential marketing has a positive and significant effect on purchasing decisions.

$\mathrm{H}_{2}$ : The community reference hypothesis test of the purchasing decision from the calculation results obtained by $\mathrm{T}$ count for $\mathrm{X}_{2}$ is equal to 2,740 is greater than $\mathrm{T}$ table 1.6581 with a significance of 0.007 smaller than the significance level of 
0.05. Means that conclusions can be drawn Ho rejected, then this indicates that the community reference variable has a positive and significant effect on purchasing decisions.

\section{Simultaneous Test (Test F)}

Used to determine the relationship between thevariables independent and thevariable dependent, whether thevariable experiential marketing $\left(\mathrm{X}_{1}\right)$ and community reference $\left(\mathrm{X}_{2}\right)$ really have an effect simultaneously (together) on the dependent variable $\mathrm{Y}$ (purchase decision).

The testing steps are as follows (Ghozali, 2005).

a. Determining Formulation Hypothesis

$\mathrm{H}_{0}: \beta 1=\beta 20$, meaning that variables $\mathrm{X}_{1}$ and $\mathrm{X}_{2}$ do not have a significant effect simultaneously on variable Y.

$\mathrm{H}_{1}: \beta 1=\beta 2 \neq 0$, meaning variable $\mathrm{X}_{1}$ and $\mathrm{X}_{2}$ has a significant effect simultaneously on variable $\mathrm{Y}$.

Table 5. Simultaneous Significance Test Results (Test F)

ANOVA $^{a}$

\begin{tabular}{ccccccc}
\hline & Model & Sum of Squares & df & Mean Square & F & Sig. \\
\hline \multirow{3}{*}{1} & Regression & 950,376 & 2 & 475,188 & 472,444 &, $000^{\mathrm{b}}$ \\
\cline { 2 - 7 } & Residual & 137,796 & 137 & 1,006 & & \\
\cline { 2 - 8 } & Total & 1088,171 & 139 & & & \\
\hline
\end{tabular}

a. Dependent Variable: Keputusan Pembelian

b. Predictors: (Constant), Referensi Komunitas, Experiential Marketing

Source: Primary data processed, 2018

Based on the results of the $F$ test in this study, the calculated $F$ value is 472,444 with a significance number (P value) of 0,000 . With a significance level of $95 \%(\alpha=0.05)$. The number of significance (P value) is $0,000<0,05$. On the basis of this comparison, then $\mathrm{H} 0$ is rejected or meaningful variables experiential marketing and referencehave a significant influence community together to variable purchase decisions.

\section{Coefficient of Determination}

The coefficient of determination $\left(\mathrm{R}^{2}\right)$ is done to see whether there is a perfect relationship or not, which is indicated by whether the change in the independent variable (experiential marketing and community reference) will be followed by the dependent variable

Table 6. Regression Test Results (Determination Coefficient) b. Determine 95\% confidence level $(\alpha=0.05)$

c. Determine significanceSignificance

- Value (P Value) $<0.05$ then $\mathrm{H}_{0}$ is rejected and $\mathrm{Ha}$ is accepted.

- Significant value (P Value) $>0.05$ then $\mathrm{H} 0$ is accepted and $\mathrm{H}_{\mathrm{a}}$ is rejected.

d. Make conclusions

- If (P Value) $<0.05$ then $\mathrm{H}_{0}$ is rejected and $\mathrm{Ha}$ is accepted. This means that the independent variables simultaneously (together) affect the dependent variable.

- If (P Value) $>0.05$ then H0 is accepted and $\mathrm{Ha}$ is rejected. This means that thevariables independent simultaneously (together) do not affect thevariable dependent.

The results of the $\mathrm{F}$ test in this study can be seen in Table 5.

(purchasing decision) in the same proportion. Testing is by looking at the value of $\mathrm{R}$ Square $\mathrm{R}^{2}$. The coefficient of determination is between 0 and 1 .

Furthermore, the small value of $\mathrm{R}^{2}$ means that the ability of independent variables to explain variations in the dependent variable is very limited. Values close to 1 mean that the independent variables provide almost all information needed to predict dependent variations (Ghozali, 2005).

The value used in this study is the adjusted $\mathrm{R} 2$ value because this value can go up or down if one independent variable is added to the tested model. Adjusted $\mathrm{R}^{2}$ value can be seen in Table 6 .

Model Summary ${ }^{\mathrm{b}}$

\begin{tabular}{lccccc}
\hline Model & $\mathrm{R}$ & $\mathrm{R}$ Square & Adjusted R Square & Std. Error of the Estimate & Durbin-Watson \\
\hline 1 &, $935^{\mathrm{a}}$ &, 873 &, 872 & 1,00290 & 1,949 \\
\hline a. Predictors: (Constant), Referensi Komunitas, Experiential Marketing & & & \\
b. Dependent Variable: Keputusan Pembelian & & & & \\
Source: Primary data processed, 2018 & & & \\
\end{tabular}


In table 6 it can be seen that the adjusted $\mathrm{R}^{2}$ value is 0.872 . This can be interpreted that the independent variable (experiential marketing and community reference) can explain the dependent variable (purchasing decision) of $87.2 \%$, while the rest is explained by other factors not examined.

\section{Discussion}

\section{The Effect of Experiential Marketing on Purchasing Decisions}

Results of research conducted by researchers can be concluded that thevariables experiential marketing are partially tested to produce $T$ count of 22.416 greater than the $\mathrm{T}$ table of 1.65581 and the value of sig of 0.000 smaller than the significance rate of 0,05 . Based on the data above, that thevariable experiential marketing in this study has a positive and significant effect on the variable consumer purchasing decisions of Brain Coffee Surabaya.

Based on the results of multiple linear regression analysis the value of $b 1=0.575$ is obtained. This means that thevariable experiential marketing affects the purchasing decision of 0.575 or has a positive effect which means that if thevariable experiential marketing increases, it will affect the purchasing decision of 0.575 .

Experiential marketing can be defined as memory or memory, as well as experiences that are embedded in the mind as well as one's feelings. This can affect the intensity of purchases from consumers through the emotions generated, also raise the value inherent in the product or brand itself.

The researcher concluded that if experiential marketing quality or high, the purchasing decision will increase. Consumers Brain Coffee Surabaya are relatively good quality.

Based on the discussion above, H0 (hypothesis 0) in this study was rejected, which means that experiential marketing has a positive and significant effect on the variable purchasing decisions.

\section{Community Reference Effect on Purchasing Decisions}

Results of research conducted by researchers can be concluded that the community reference variable is tested partially to produce $\mathrm{T}$ count of 2.740 greater than $\mathrm{T}$ table of 1.65581 and sig value of 0.007 smaller than the significance rate of 0.05 . Based on the data above, that the community reference variable in this study has a positive and significant effect on the variable consumer purchasing decisions of Brain Coffee Surabaya.

Based on the results of multiple linear regression analysis, the value of $\mathrm{b} 2=0.161$. This means that the community reference variable affects the purchasing decision of 0.161 or has a positive effect, which means that if the community reference variable increases, it will affect the purchasing decision of 0.161 .

Community reference in this research explain the information and experience of one group member that influences other members to persuade in purchasing at Brain Coffee Surabaya.

The researcher concluded that if the community reference is of high quality or high, the purchasing decision will increase. Consumers Brain Coffee Surabaya are relatively good quality.

Based on the discussion above that $\mathrm{H}_{0}$ (hypothesis 0) in this study is rejected, which means that community references have a positive and significant effect on the variable purchase decisions.

\section{Effect of Experiential Marketing and Community Resources to Purchase Decisions}

Based on the research that has been done by the researchers that the variable experiential marketing and community reference positive and significant effect simultaneously on consumer purchasing decisions Brain Coffee Surabaya. This is based on the results of thetest calculation $\mathrm{F}$, by comparing $\mathrm{F}$ count and $\mathrm{F}$ table, then obtained F count $(472,444)$ greater than F table (3.06), and the significance value is 0,000 smaller than the significance level of 0.05 .

The better or higher experiential marketing and community references that are owned and offered by a company, it will be able to improve purchasing decisions.

The results of the analysis of the coefficient of determination $\left(\mathrm{R}^{2}\right)$ figures show Adjusted $R$ Square 0.872 or $87.2 \%$. This means that $87.2 \%$ of experiential marketing and community reference variables can explain the variance of purchase decision variables, the remaining $12.8 \%$ can be explained by other variables outside of the research variables that were not discussed in this study.

The analysis and data above show experiential marketing and community references simultaneously have a positive and significant effect on purchasing decisions. 
Based on the analysis and the data above, it can be concluded that $\mathrm{H}_{2}$ (Hypothesis 2) in this study, namely, experiential marketing and community reference simultaneously has a positive and significant effect simultaneously on consumer purchasing decisions of Brain Coffee Surabaya, accepted. By increasing experiential marketing and community reference it will have a positive effect on purchasing decisions.

\section{Conclusion}

Based on the results of the research and discussion that have been conducted, the conclusion can be drawn as follows:

1. Experiential marketing has a positive and significant effect on purchasing decisions.

2. Community reference positive and significant effect on purchasing decisions.

3. Experiential marketing and community references simultaneously positive and significant effect on purchasing decisions.

\section{References}

Alkilani. K. et al, "The Impact of Experiential Marketing and Customer Satisfaction on Customer Commitment in the World of Social Networks",Asian Social Science Vol 9 No. 1, 2013.

Budiasih, Y. (2012). Struktur Organisasi, Desain Kerja, Budaya Organisasi, dan Pengaruhnya Terhadap Produktivitas Karyawan PT. XX di Jakarta. Jurnal Liquidity, 1(2), 99-105. Diunduh dari http://www.liquidity.stiead.ac.id

Chairiza. (2012). Pengaruh Bauran Pemasaran Terhadap Kepuasan Konsumen Pada Hotel Andalas di Bandar Lampung. (Tesis). Universitas Lampung. Bandar Lampung. $61 \mathrm{hlm}$.

Danang Sunyoto. (2012). Dasar-dasar manajemen pemasaran. Cetakan Pertama. Yogyakarta : CAPS.

Hasan, Ali. (2013), Marketing dan Kasus-Kasus Pilihan, Yogyakarta, CAPS.

Hendarsono Gersom dan Sugiono (2013): analisa pengaruh experiential marketing terhadap minat beli ulang konsumen cafe buntos 99 sidoarjo , jurnal manajemen pemasaran Vol. 1, No. 2, (2013) 1-8

Indrawati. (2015).Metode Penelitian Manajemen dan Bisnis Konvergensi Teknologi Komunikasi dan Informasi, Bandung : Aditama.
Kotler dan Keller, (2012), Marketing Management Edisi 14, Global Edition.Pearson Prentice Hall. Kotler dan Armstrong, Principles of Marketing15th Ed. United States,Pearson, 2014. p. 405

Kotler, Philip and Gary Armstrong. (2012). Prinsipprinsip Pemasaran. Edisi 13. Jilid 1. Jakarta: Erlangga.

Kotler, Philip dan Gary Armstrong. (2014), Principles of Marketing, Fifteenth Edition, Harlow, Pearson Education.

Kurniawan, Albert. (2014). Metode Riset Untuk Ekonomi\&Bisnis, Penerbit Alfabeta, Bandung

Maghnati, Farshad., Kwek Choon Ling dan Amir Nasermoadeli. (2012). Exploring the Relationship between Experiential Marketing and Experiential Value in the Smartphone Industry. International Business Research; Vol. 5, No. 11.

Mulyatiningsih, Endang. (2012). Metode Penelitian Terapan Bidang Pendidikan. Bandung: Alfabeta.

Novia, Vivi. (2012). Pengaruh Experiential Marketing Terhadap Customer Loyalty Pada pelanggan Restoran Koki Sunda Di Pekanbaru. Jurnal Manajemen Universitas Riau 2012.

Santoso, Singgih. (2012). Analisis SPSS pada Statistik Parametrik. Jakarta: PT. Elex Media Komputindo.

Sugiyono (2011). Metode penelitian kuantitatif kualitatif dan RED. Alfabeta

Sugiyono, (2012). Statistik untuk Penelitian, Bandung: Alfabeta,

Sugiyono. (2013). Metode Penelitian Pendidikan (Pendekatan Kuantitatif, kualitatif, dan RED). Bandung: Alfabeta.

Sugiyono. (2014). Metode Penelitian Kuantitatif, Kualitatif, dan Kombinasi (Mixed Methods). Bandung: Alfabeta

Sugiyono. (2015). Metode Penelitian Pendidikan (Pendekatan Kuantitatif, Kualitatif dan RED). Penerbit CV. Alfabeta: Bandung.

Sujarweni, Wiratna.2014. SPSS Untuk Penelitian. Pustaka Baru Press, Yogyakarta.

Sujarweni, Wiratna. 2015. SPSS Untuk Penelitian. Yogyakarta: Pustaka Baru Press.

Sunjoyo, dkk, 2013. Aplikasi SPSS Untuk Smart Riset. Alfabeta, Bandung.

TP Mulya dan A Wulandari, (2016)," Pengaruh Brand Image Terhadap Keputusan Pembelian Pada Chatime (Studi Pada Mahasiswa Universitas 
Telkom 2016)", Prosiding SNaPP: Sosial, Ekonomi dan Humaniora 6 (1), 229-236.

Zikmund, G. W dan Babin. B. J. (2013), Menjelajahi Riset Pemasaran, $10^{\text {th }}$ ed, Jakarta: Penerbit Salemba Empat. 